\title{
Study Outcome Measure Name
}

National Cancer Institute

\section{Source}

National Cancer Institute. Study Outcome Measure Name. NCI Thesaurus. Code C94092.

A non-unique textual identifier for the study outcome measure. 